\title{
Fishes of the Amazon: diversity and beyond
}

\author{
ADALBERTO LUIS VAL \\ Instituto Nacional de Pesquisas da Amazônia - INPA/MCTIC, Laboratory of Ecophysiology and \\ Molecular Evolution, Ave. Andre Araujo, 2936, 69080-971 Manaus, AM, Brazil \\ Manuscript received on March 5, 2019; accepted for publication on March 23, 2019
}

\begin{abstract}
How to cite: VAL AL. 2019. Fishes of the Amazon: diversity and beyond. An Acad Bras Cienc 91: e20190260. DOI 10.1590/0001-3765201920190260.
\end{abstract}

\begin{abstract}
The Amazon basin houses a particular group of freshwater organisms, whose study tells the geological history of the region, how biological diversity was shaped, how it is maintained, and what it hides. The fish of the Amazon is represented by more than 3,000 known species distributed from the basal groups up to the more specialized ones. This species richness hides a diversity of adaptations that are dispersed at all levels of the biological organization. In this summary of the conference delivered at the Brazil-France Bilateral Symposium, held in Manaus in 2018, we describe two aspects of the hidden world of adaptive diversity: adaptations to changes in dissolved oxygen and the abilities of the Rio Negro fish to face acidic and ion-poor waters of their habitats. Also, we present the vulnerability of Amazonian fish to ongoing climate changes. Then, very briefly, we call attention to the many hidden biological processes that allow these fish species to survive their environments, much of which is unknown. Indeed, however, they are intricately related to men, either by responding to environmental disturbances that we have caused, or by containing information that contributes to improving the quality of the environment in which we live.
\end{abstract}

Key words: Amazonia, biodiversity, adaptations, hypoxia, dissolved organic carbon, climate changes.

\section{INTRODUCTION}

Extending across all countries in the north of South America, the Amazon biome includes unmeasurable qualities. The biome is better described by its immeasurableness and by its unknowns than by its known conditions. This statement does not mean a lack of information about the region; on the contrary, the volume of existing knowledge is significant. However, given the unparalleled diversity of natural resources, dynamic environments that vary in space and time, and a biological diversity that hides a vast number of organisms yet to be described by

E-mail: dalval@inpa.gov.br

ORCid: https://orcid.org/0000-0002-3823-3868 science, production of robust information about the region must be considerably expanded. It means a treasure for all the Amazonian countries and should occupy a prominent position in a sound science and technology agenda. However, none of the Amazon countries, including Brazil, has a robust science and technology agenda to explore the hidden potential of any small portion of the region.

The Amazon biome has an area of 7.76 million square kilometers, of which more than five million are in the Brazilian territory. Comparatively, the Amazon area in Brazil is larger than the sum of the areas of all European countries. It is in this region that the longest and most abundant river on the planet runs: The Amazon River, 6,992 km long, 
is rivaled only by the Nile River, $6,671 \mathrm{~km}$. It is along its route, from the Nevado Mismi in Peru to its mouth in the Atlantic Ocean, that the Amazon River collects water from the different tributaries in the North and South to discharge more than $250,000 \mathrm{~m}^{3}$ of water per second in the ocean, which represents approximately $20 \%$ of all freshwater flowing into all world's oceans. Even its tributaries have big numbers: The Negro river, for example, discharges $28,000 \mathrm{~m}^{3}$ of water per second in the Amazon River. Therefore, it is a unique space.

Also, the basin is neither homogeneous nor monotonous. Each small space is unique and undergoes dynamic changes over a single day. There are three types of water: white, black and clear water, each with specific characteristics. For example, while the Amazon river has a $\mathrm{pH}$ close to neutral, the waters of the Rio Negro are acidic and poor in ions (Sioli 1984, Val and Almeida-Val 1995). There is no physical barrier between the different types of water, i.e., the aquatic biota can freely move among the different types of water.

On the other hand, river water levels vary significantly throughout the year, with pulses of flood and ebb (Junk et al. 1989, Schöngart and Junk 2007). During flood periods, significant portions of the land forest are flooded making transient new habitats available to the aquatic biota; during ebb periods, these habitats do not exist. At the same time, several water characteristics vary throughout the day, both during periods of high water and during drought, being oxygen availability the most relevant aspect from the physiological point of view. The water in many places varies from anoxic to hyperoxic, as observed in floodplain regions (Val and Almeida-Val 1995). Geographical variations in the availability of dissolved oxygen in water can also be striking, such as those observed for the Trombetas and Purus rivers (Rocha-Silva et al. 2011).

It is in this diverse and dynamic environment that one finds a rich ichthyofauna, almost without parallels (Val and Almeida-Val 1995). There are about 3,000 species of fish distributed from the basal groups to the more specialized ones, such as the Cichliformes until recently included among the Perciformes. Among these fish are small fish species such as the cardinal, weighting few grams, up to the giants pirarucu and piraíba, weighing more than 250 kilograms. Many of these species emerged millions of years ago and have evolved in challenging environments. Amazonian fish have always confronted scientists who have visited the region as soon as the first expeditions were organized aiming the unknown world. Indeed, to maintain this diversity of fish, other equally diverse aquatic organisms must be present. The myriad of organisms composing the biota, including that of nearby "terra firme", is indeed biologically interdependent. Many species are endemic and occur only in the Amazon, some of which occur just in specific sub-regions. For example, in the Duke biological reserve, the average richness is similar in the different sampling sites; however, the composition is tightly related to the chemical and physical characteristics of the streams, leading to a differentiated distribution in small spaces within the 100ha reserve (Mendonça et al. 2005), pointing to the existence of many species to be described.

On the other hand, the presence of long-distance migratory species needs to be pointed out, not only the giant catfish that migrate thousands of miles across the basin but also several species of Characiformes, such as the jaraqui and matrinchã, that migrate from the headwaters of several tributaries to the main central river channel. Many are the factors that have contributed to the diversification of fish species in the Amazon. These factors include: the formation of the basin, which begins with the Andes uplift; its unparalleled size; the dynamics of the basin; the pulses of flood and ebb; its open character with connections with the North and with the South; the paucity of some part of the Central Amazon; and the 
continuing evolution and adjustments of genetic and physiological features.

\section{A DIVERSITY OF BIOLOGICAL STRATEGIES TO SURVIVE LOW OXYGEN WATERS}

Amazonian fish have developed a wide array of adaptations throughout the evolutionary process to optimize oxygen transfer processes to meet metabolic demands. Hypoxia has been an everpresent challenge for fish in the region (Val et al. 1998). Many species can breathe air, some of which do so continuously and are called obligatory air-breathing species, that is, they breathe air independently of the amount of dissolved oxygen; others are called facultative air-breathing species, that is, they only breathe air when there is insufficient dissolved oxygen to meet their metabolic demands. These fish use different structures to uptake oxygen: Lepidosiren, the South American lungfish, uses a real lung, while Arapaima, also an obligatory air-breather, uses a modified swim-bladder that resembles a lung. Among the facultative airbreathing fish, the oxygen is taken up through the skin, the vascularized region of the stomach and intestine, diverticula of the mouth, gills, and pharynx, as well as through a partially vascularized swim-bladder (Table I). For facultative air-breathing fish, the gills are functional and therefore, during aerial respiration, there occur gill adjustments to secure carbon dioxide excretion and to avoid loss of oxygen to the external hypoxic environment.

Among the species of gill respiration, unable to capture oxygen directly from the air, adaptations occur at all levels of the biological organization, from the behavioral to the molecular level (Figure 1). At the behavioral level, there are several strategies, but two with a relatively high occurrence, namely lateral migration and respiration at the aquatic surface. Many species of fish migrate laterally from the river to the flooded forest during the day and back to the river before nightfall since in the running water of the river are regularly normoxic, while in the flooded forest the oxygen levels may reach zero at night. These lateral migrations are associated with several biological processes, including breeding (Cox-Fernandes 1997). Several questions arise from this observation and are related to geo-positioning and oxygen sensing. For long-migratory fish, there are already studies relating physiological processes and geo-positioning (Krylov et al. 2014, Putman et al. 2014), but information for lateral migrations involving relatively reduced distances is not yet available. Aquatic surface respiration (ASR) involves repositioning the animal near the surface of the water column so that the animal can pump through the gills the thin surface layer of the water column that is richer in oxygen. Aquatic surface respiration is an essential alternative to aerial respiration and is present in a significant number of species; the oxygen threshold that triggers positioning near the surface of the water column, however, varies between species (Kramer and McClure 1982). For air-breathing species and those that can breathe on the aquatic surface, many other challenges need to be studied. Among them, the risk of aerial predation that may have important ecological implications, but is unknown (Shingles et al. 2005, Abdallah et al. 2015), and exposure to ultraviolet radiation (Groff et al. 2010). Several questions arise regarding the processes that control ASR.

A fascinating example of breathing on the aquatic surface is provided by tambaqui, Colossoma macropomum, an emblematic species for the Amazon. When exposed to low oxygen availability, specimens of this species can expand the lower lips that are used to efficiently capture the thin surface layer of the water column (Braum 1983, Saint-Paul 1984, Val 1995). Below 10\% water saturation, all specimens have lips and skim the water surface. In the same way that the lips appear when there is low availability of oxygen, they regress when normoxia is reestablished. However, what is the physiological mechanism 
TABLE I

Examples of facultative and obligatory air-breathing fish of the Amazon and organs used aerial respiration.

\begin{tabular}{|c|c|c|c|c|c|}
\hline \multirow[b]{2}{*}{$\begin{array}{l}\text { Family } \\
\text { (Species) }\end{array}$} & \multirow{2}{*}{$\begin{array}{c}\text { Air-breathing style } \\
\text { Obligatory (O) } \\
\text { Facultative (F) }\end{array}$} & \multicolumn{4}{|c|}{ Organs used for aerial respiration } \\
\hline & & Swimbladder & Skin & $\begin{array}{l}\text { Stomach and } \\
\text { Intestine }\end{array}$ & $\begin{array}{c}\text { Pharyngeal, } \\
\text { branchial } \\
\text { and mouth } \\
\text { diverticula }\end{array}$ \\
\hline $\begin{array}{c}\text { Lepidosirenidae } \\
\text { (Lepidosiren paradoxa) }\end{array}$ & $\mathrm{O}$ & * & & & \\
\hline $\begin{array}{c}\text { Arapaimidae } \\
(\text { Arapaima gigas })\end{array}$ & $\mathrm{O}$ & $*$ & & & \\
\hline $\begin{array}{c}\text { Erythrinidae } \\
\text { (Erythrinus erythrinus) }\end{array}$ & $\mathrm{F}$ & $*$ & * & & \\
\hline $\begin{array}{c}\text { Doradidae } \\
\text { (Corydoras julii) }\end{array}$ & $\mathrm{F}$ & & & $*$ & \\
\hline $\begin{array}{c}\text { Callichthyidae } \\
\text { (Callichthys callichthys) }\end{array}$ & $\mathrm{F}$ & & & $*$ & \\
\hline $\begin{array}{l}\text { Loricariidae } \\
\text { (Pterygoplichthys } \\
\text { multiradiatus) }\end{array}$ & $\mathrm{F}$ & & & * & \\
\hline $\begin{array}{l}\text { Rhamphichthyidae } \\
\text { (Rhamphichthys } \\
\text { marmoratus) }\end{array}$ & $\mathrm{F}$ & & & & * \\
\hline $\begin{array}{c}\text { Electrophoridae } \\
\text { (Electrophorus electricus) }\end{array}$ & $\mathrm{O}$ & & & & * \\
\hline $\begin{array}{l}\text { Synbranchidae } \\
\text { (Synbranchus } \\
\text { marmoratus) }\end{array}$ & $\mathrm{F}$ & & & & * \\
\hline
\end{tabular}

that leads to the expansion and regression of the tambaqui's lips? The processes of oxygen sensing are possibly involved, and several authors have sought to analyze the expression of genes related to lip formation as well as innervation of the lips of this species (Sundin et al. 2000, Fagundes 2012). Another compelling example of morphological adjustments in animals exposed to hypoxia is the branchial remodeling exhibited by Astronotus ocellatus. When in hypoxia, the gills of A. ocellatus present reduced abundance of MRCs (mitochondria rich cell) on the filamentous surface; lack of visible MRCs on the lamellar epithelium; a more straightforward pattern of the PVCs (pavement cell) surface with a smooth central part and a few concentric micro-ridges; and significantly reduced apical crypt surface area (Wood et al. 2009). Again, the controlling mechanisms of these morphological reorganization processes are unknown suggesting, from what has hitherto been described, that these mechanisms are complex.

The transfer of oxygen from the environment to meet the metabolic demands also depends on biochemical adjustments. Two sets of adjustments are highlighted here: the multiplicity of hemoglobins and the intra-erythrocytic organic phosphates. Fish commonly present multiple hemoglobins. The different types of hemoglobins have different functional properties in several species, and in many species, the proportion between them varies according to environmental characteristics and physiological demands of the animal (Val et al. 


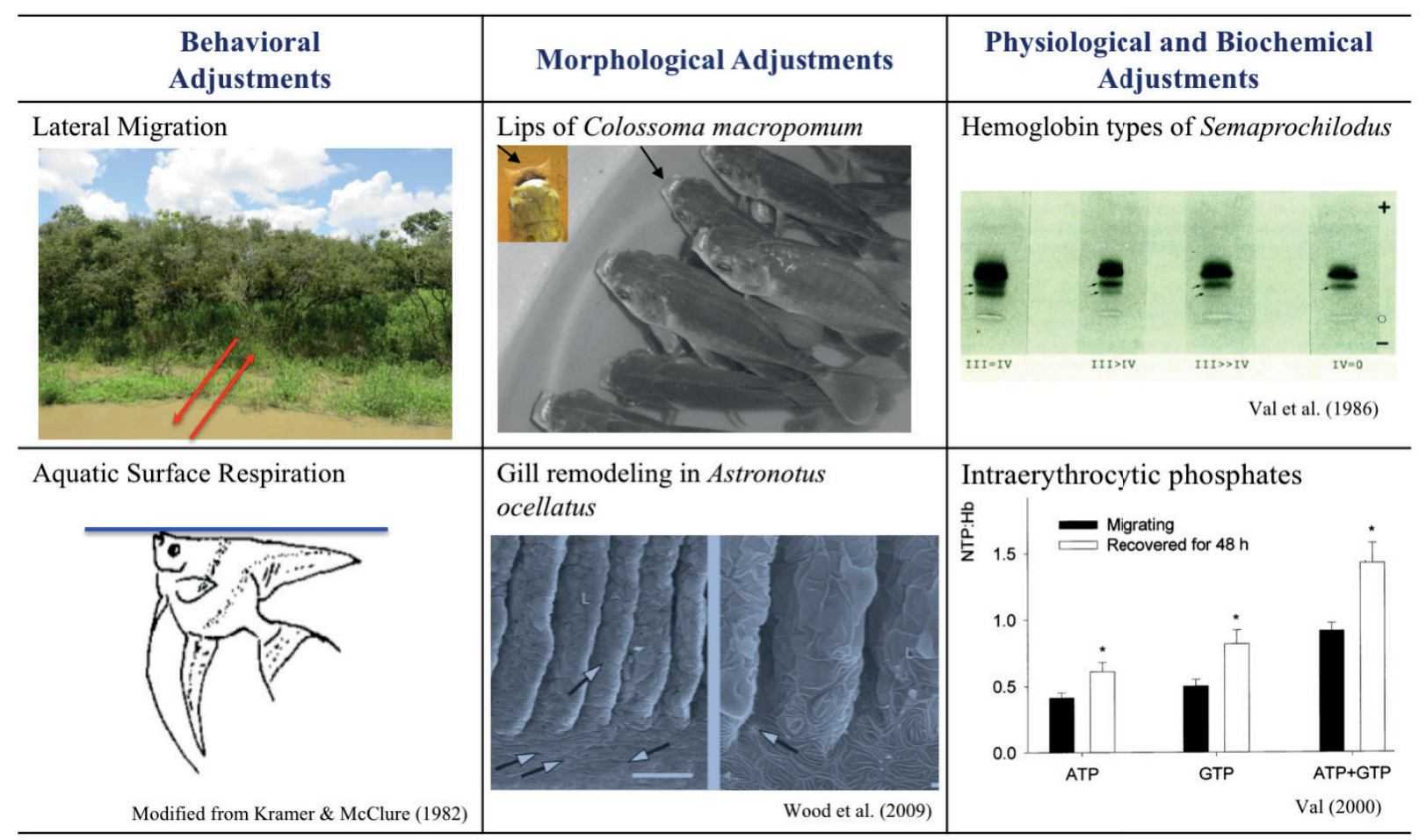

Figure 1 - Behavioral, morphological, physiological and biochemical adjustments aiding oxygen transfer in fish of the Amazon.

1986a, b, Weber et al. 2000, Rutjes et al. 2007). It is essential to mention that the existence of multiple hemoglobins in fish erythrocytes continually exposed to episodes of hypoxia is adaptively vital because it limits their precipitation in the cell since they are less soluble in their deoxygenated state. Organic erythrocyte phosphates are negative modulators of $\mathrm{Hb}-\mathrm{O}_{2}$ affinity. ATP and GTP are the main phosphates found in the erythrocytes of tropical fish and, in general, the GTP concentrations are higher than the ATP concentrations. The levels of these two erythrocytic phosphates are reduced in fish exposed to environmental and physiological hypoxic conditions (Val et al. 2015), with GTP concentrations being decreased much faster than ATP concentrations. It is possible that this is related to the use of GTP by EIF-1 $\alpha$ (Eukaryotic Initiation Factor) in the processes of protein synthesis that happen when organisms are required to adjust to the hypoxic environment. In addition to ATP and GTP, two other phosphates were described in Amazonian fish: 2,3DPG (2,3 diphosphoglycerate) in Hoplosternum littorale erythrocytes, and IPP (Inositol pentaphosphate) in adult Arapaima gigas (Isaacks et al. 1977, Val 2000). The control mechanisms of the 2,3DPG concentration in Hoplosternum erythrocytes appear to be related to water temperature (Val and Almeida-Val 1995), while the increase of IPP level during the first year of life of pirarucu appear to be related to decreases of ATP and GTP concentration (Val et al. 1992). Recent studies show a redundancy of IPP biosynthesis routes in pirarucu erythrocytes (Ribeiro 2017). In summary, the immense diversity of species hides an equally broad set of adaptive mechanisms at all levels of the biological organization that needs to be studied and described.

\section{FISH TACKLING THE ACIDIC AND ION- POOR WATERS OF RIO NEGRO}

The acidic and ion-poor water of black water rivers, such as the Rio Negro, impose additional challenges to the fish regarding ion homeostasis. In general, freshwater fish tend to lose salts to the 
environment, which can be accentuated in acidic environments and be even more challenging in ionpoor environments, in particular, in waters deficient in calcium. Initial analyses of fish of the Rio Negro showed that they experience ion disturbances only when the water $\mathrm{pH}$ is lowered to $\mathrm{pH} 3$. Under $\mathrm{pH}$ 3 they face a 3 to 5 -fold loss of $\mathrm{Na}$ and $\mathrm{Cl}$, which is, however, much smaller than the losses observed for less tolerant fish species. Also, these initial observations evidenced a high gill affinity for $\mathrm{Ca}$ (Gonzalez et al. 1998, Wood et al. 1998). These data served as a stimulus for the organization of an expedition to the Rio Negro to expand the analyzes for other species. Two basic patterns emerged from that expedition: a) species such as Corydoras julii and Hemigrammus sp, which present significant efflux of $\mathrm{Na}$ at $\mathrm{pH} 4$ (less tolerant species) (Fig. 2); and b) species such as Carnegiella strigata and Apistogramma sp, in which the sodium flux is not affected at pH4 and only moderately stimulated at pH 3.5 (Gonzalez et al. 2002). Simultaneously, this later situation was also showed for tambaqui specimens that presented significant disturbances of ion fluxes only when exposed to $\mathrm{pH} 3$ (Wood et al. 1998).

Subsequent analysis has sought to elucidate the mechanisms and effects of typical characteristics of the Rio Negro on the processes of ion regulation in fish that live in black waters. In these studies it was clearly observed that: a) acclimation of cardinal tetras to $\mathrm{DOC}+$ low $\mathrm{pH}$ resulted in an increase of whole body $\mathrm{Na}$ by $31 \%$ and $\mathrm{Ca}$ by $166 \%$ compared to animals acclimated to low $\mathrm{pH}$ alone; b) DOC protects cardinal tetra acclimated to soft-acidic water by preventing excessive $\mathrm{Na}$ losses and by stimulating Ca uptake; and (c) Rio Negro DOC provided almost perfect protection against ionoregulatory disturbances associated with an acute exposure to low $\mathrm{pH}(\mathrm{pH} 4)$ in ionpoor water in the non-native fish Danio rerio (Matsuo and Val 2007, Duarte et al. 2016). There are still many questions to answer. For example, what is the influence of different fractions of DOC on ion regulation in fish of the Rio Negro? Since the chemical characteristics of DOC vary seasonally and geographically, how do fish respond to these variations? Is there an interaction of DOC in paracellular junctions? If so, how does this interaction occur?

Some species of fish, on the other hand, can migrate back and forth and even thrive in the different types of water in the Amazon. Are these species able to adjust gene transcription to be in different environments such as the waters of the Rio Negro? We analyzed this question using the Triportheus albus as a model, which co-occurs in black, white and clear waters. Specimens were sampled in the three different types of water, and the differential gene expression was determined. Thousands of genes are differentially expressed between specimens of the Rio Negro and the Solimões River (approximately 4,000 genes) and between specimens of the Rio Negro and the Tapajós River (approximately 9,000 genes), with a reduced number of genes (1,551 genes) commonly regulated. It is interesting, however, that the primarily regulated genes are related to (a) decrease in cellular permeability, in particular, the genes coding for claudin proteins, actn 4 , itgb3b, DSP, Gap junction protein, and Ca2C-ATPase, and to (b) ionic regulation and acid-base, in particular the gene coding for rhcG1, slc9a6a (NHE), ATP6V0A2, NaC/KC-ATPase, slc26a4 (pedrin) and slc4a4b (Araújo et al. 2017).

These studies show that biological diversity in the Amazon is much higher than we see. Also, these studies confront us with a broad set of questions that broadens scientific interest in the Amazonian biome. Understanding how these organisms are capable of facing the environment in which they live can serve as a model for the design of actions for the conservation of the environment and the design of solutions to the challenges that we are ourselves facing. 
Less Tolerant

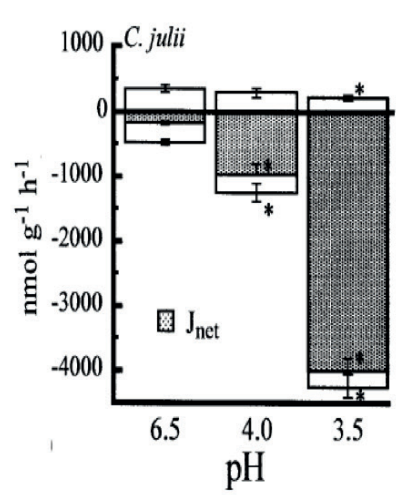

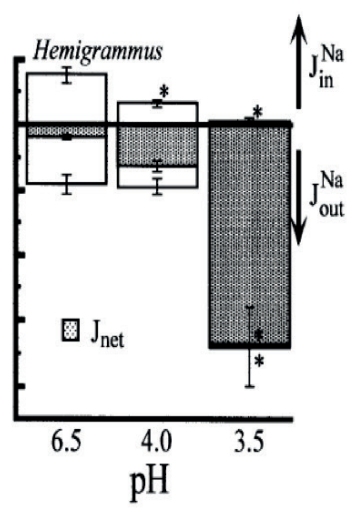

More Tolerant

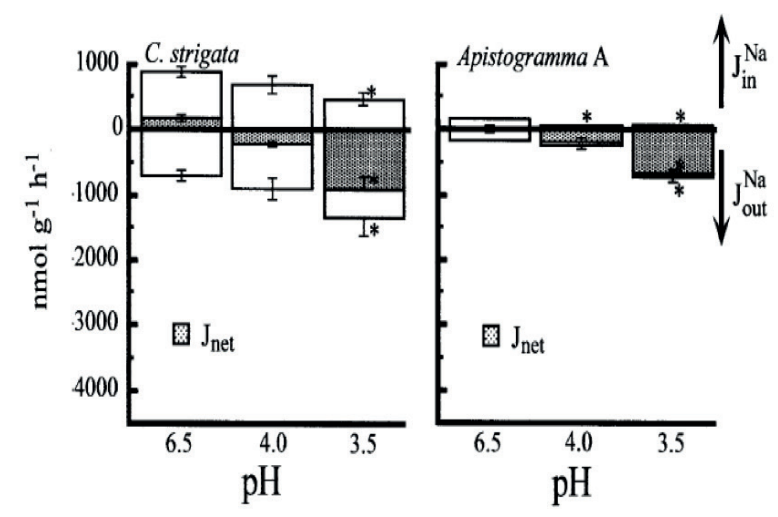

Figure 2 - Sodium influx $\left(J_{\text {in }}^{N a}\right)$, efflux $\left(J_{\text {out }}^{N a}\right)$ and net flux $\left(J_{\text {net }}\right)$ of four species of fish from Rio Negro exposed to acidic water. From Gonzalez et al. (2002).

\section{GLOBAL WARMING - NEW CHALLENGES FOR FISH FROM THE AMAZON}

The inherent challenges posed by the physical and chemical characteristics of the Amazonian waters, as well as their dynamicity, may be exacerbated by ongoing climate changes. Warmer waters with lower pHs and less dissolved oxygen are some of the consequences of climate change in the Amazon. To analyze the effects of this new challenges on fish, four environmental rooms were constructed at INPA's main campus: a control room that reproduces real-time the conditions in the forest, and three experimental rooms in which the mild, intermediate and extreme scenarios, as projected by the IPCC (Intergovernmental Panel on Climate Change) for the year 2100 (IPCC 2013) are also adjusted in real time. Several experiments were performed there, and two of them are described herein. The two were completed with tambaqui. In the first one, we observed a marked effect of the intermediate and drastic scenarios on the larvae. In a short period of two weeks, the proportion of larvae with some type of skeletal anomaly (lordosis, kyphosis, scoliosis, mandibular malformation, among others) increased dramatically in animals exposed to intermediate and drastic scenarios in relation to the control, compromising about $40 \%$ of the larvae with one or more types of anomalies (Lopes et al. 2018). If this high proportion of skeletal anomalies persists in the face of ongoing climate change, two aspects need to be carefully considered: firstly, concerning the conservation processes of fish species, and secondly, concerning food security, because tambaqui is an important food source for humans. For larger, growing animals, higher feed intake is expected in warmer environments. In fact, for the tambaqui in the intermediate and drastic scenarios we observed a higher feed intake; however, this increase in feed consumption was not accompanied by a proportional increase in weight, i.e., the animal eats more but does not grow (Oliveira and Val 2017), which represents substantial limitations for fish farming.

The effects of warming on Amazonian waters may also have more significant consequences. Throughout the evolutionary process, it is possible that there has been a trade-off between lifestyle/ energetic requirements and warming. In studying fish species from Ducke reserve, we observed a correlation between routine and thermal maximum metabolic rate, and between metabolic rate and 
activity levels. We observed that specimens of Characidae and Crenuchidae presented reduced abilities to cope with warming events and so, reduced thermal tolerance. The studied species of Characidae and Crenuchidae presented CTMax (Critical Thermal Maximum) of 32 and $35^{\circ} \mathrm{C}$, respectively. As a comparison, the $\mathrm{CT} \max$ for Cichlidae species was higher than $38^{\circ} \mathrm{C}$ (Campos et al. 2018). These results suggest that small increases in environmental temperature will push many species of the Amazon over their limits.

\section{FUTURE DIRECTIONS}

It is clear that the observed biological richness hides a vast array of genetic, biochemical, physiological and behavioral attributes that allow fish to explore their habitats extensively. We are very far from knowing this set of attributes. What we do not know far exceeds what we know. However, what we know already allows us to design actions for the conservation of the environment as well as for the generation of products and processes to optimize productive chains and improve human quality of life, as mentioned. So, the hidden part of the Amazonian diversity represents a natural resource without parallels. Thus, although it is necessary to invest in knowledge of the biodiversity of the Amazon, it is urgent to use existing information.

\section{ACKNOWLEDGMENTS}

Our work has been supported in Brazil by Coordenação de Aperfeiçoamento de Pessoal de Nível Superior (CAPES), Conselho Nacional de Desenvolvimento Científico e Tecnológico (CNPq), FAPEAM, FINEP, Copper Association, Leverhulme Foundation, and INPA. ALV is a recipient of a research fellowship from $\mathrm{CNPq}$.

\section{REFERENCES}

ABDALLAH SJ, THOMAS BS AND JONZ MG. 2015. Aquatic surface respiration and swimming behaviour in adult and developing zebrafish exposed to hypoxia. J Exp Biol 218: 1777-1786.

ARAÚJO JD, GHELFI A AND VAL AL. 2017. Triportheus albus Cope, 1872 in the Blackwater, Clearwater, and Whitewater of the Amazon: A Case of Phenotypic Plasticity? Front Genet 8: 114.

BRAUM E. 1983. Beobachtungen uber line reversible lippenextension und ihre roler beider notatmung von Brycon spec. (Pisces, Characidae) und Colossoma macropomum (Pisces, Serrasalmidae). Amazoniana 7: 355-374.

CAMPOS D, ALMEIDA-VAL VMF AND VAL AL. 2018. The influence of lifestyle and swimming behavior on metabolic rate and thermal tolerance of twelve Amazon forest stream fish species. J Therm Biol 72: 148-154.

COX-FERNANDES C. 1997. Lateral migration of fishes in Amazon floodplains. Ecol Freshw Fishes 6: 36-44.

DUARTE RM, SCOTT SMITH D, VAL ALAND WOOD CM. 2016. Dissolved organic carbon from the upper Rio Negro protects zebrafish (Danio rerio) against ionoregulatory disturbances caused by low pH exposure. Sci Rep 6: 20377.

FAGUNDES DB. 2012. Identificação de genes potencialmente envolvidos na formação do edema labial na espécie Colossoma macropomum (Cuvier, 1818). MSc thesis. INPA. (Unpublished).

GONZALEZ R, WOOD C, WILSON R, PATRICK M, BERGMAN H, NARAHARA A AND VAL A. 1998. Effects of water $\mathrm{pH}$ and calcium concentration on ion balance in fish of the rio Negro, Amazon. Physiol Zool 71: $15-22$.

GONZALEZ RJ, WILSON RW, WOOD CM, PATRICK ML AND VAL AL. 2002. Diverse strategies for ion regulation in fish collected from the ion-poor, acidic Rio Negro. Physiol Biochem Zool 75: 37-47.

GROFF A, SILVA J, NUNES E, IANISTCKI M, OLIVEIRA A, OLIVEIRA C, VAL AL AND HENRIQUES J. 2010. UVA/UVB induced lesion repair and genotoxicity in the Amazonian fishes Colossoma macropomum and Arapaima gigas. Aquat Toxicol 99: 93-99.

IPCC. 2013. Working Group I contribution to the IPCC $5^{\text {th }}$ Assessment Report "Climate Change 2013: The Physical Science Basis".

ISAACKS RE, KIM H D, BARTLETT GR AND HARKNESS DR. 1977. Inositol pentaphosphate in erythrocytes of a freshwater fish, pirarucu (Arapaima gigas). Life Sci 20: 987-990.

JUNK WJ, BAYLEY PB AND SPARKS RE. 1989. The flood pulse concept in River-Floodplain Systems. In: Dodge DP (Ed), Proceedings of the International Large River Symposium, Vol 106. Can. Spec. Publ. Fish. Aquat. Sci., Canada, p 110-127.

KRAMER DL AND MCCLURE M. 1982. Aquatic surface respiration, a widespread adaptation to hypoxia in tropical freshwater fishes. Env Biol Fishes 7: 47-55. 
KRYLOV VV, IZYUMOV YG, IZVEKOV EI AND NEPOMNYASHCHIKH VA. 2014. Magnetic Fields and Fish Behavior. Biol Bull Rev 4: 222-231.

LOPES IG, ATAÚJO-DAIKIRI TB, KOJIMA JT, VAL AL AND PORTELLA MC. 2018. Predicted 2100 climate scenarios affects growth and skeletal development of tambaqui (Colossoma macropomum) larvae. Ecol Evol 2018: 1-10.

MATSUO AYO AND VAL AL. 2007. Acclimation to humic substances prevents whole body sodium loss and stimulates branchial calcium uptake capacity in cardinal tetras Paracheirodon axelrodi (Schultz) subjected to extremely low pH. J Fish Biol 70: 989-1000.

MENDONÇA FP, MAGNUSSON WE AND ZUANON J. 2005. Relationships between habitat characteristics and fish assemblages in small streams of central Amazonia. Copeia 2005: 751-764.

OLIVEIRA AM AND VAL AL. 2017. Effects of climate scenarios on the growth and physiology of the Amazonian fish tambaqui (Colossoma macropomum) (Characiformes: Serrasalmidae). Hydrobiologia 789: 167-178.

PUTMAN NF, SCANLAN MM, BILLMAN EJ, O'NEIL J, COUTURE RB, QUINN TP, LOHMANN KJ AND NOAKES DLG. 2014. An inherited magnetic map guides ocean navigation in juvenile Pacific salmon. Current Biol 24: 446-450.

RIBEIRO GO. 2017. Biossintese de inositol $(1,3,4,5,6)$-pentafosfato em eritrocitos de Arapaima gigas (SCHINZ, 1822). MSc thesis. Instituto Nacional de Pesquisas da Amazônia. (Unpublished).

ROCHA-SILVA MS, CUNHA HB, MIRANDA SAF, SANTANA GP AND PASCOALOTO D. 2011. Química das águas de superfície dos rios da Bacia Amazônia: uma contribuição para classificação de acordo com seus usos preponderantes. Paper presented at the XIX Simpósio Brasileiro de Recursos Hídricos, Maceió, AL, Brasil.

RUTJES HA, NIEVEEN MC, WEBER RE, WITTE F AND VAN DEN THILLART GEEJM. 2007. Multiple strategies of Lake Victoria cichlids to cope with lifelong hypoxia include hemoglobin switching. Amer J Physiol 293: R1376-R1383.

SAINT-PAUL U. 1984. Physiological adaptation to hypoxia of a neotropical characoid fish Colossoma macropomum, Serrasalmidae. Env Biol Fishes 11: 53-62.

SCHÖNGART J AND JUNK WJ. 2007. Forecasting the floodpulse in Central Amazonia by ENSO-indices. J Hydrol 335: 124-132.

SHINGLES A, MCKENZIE DJ, CLAIREAUX G AND DOMENICI P. 2005. Reflex cardioventilatory responses to hypoxia in the flathead gray mullet (Mugil cephalus) and their behavioral modulation by perceived threat of predation and water turbidity. Physiol Biochem Zool 78: 744-755.

SIOLI H. 1984. The Amazon. Limnology and landscape ecology of a might tropical river and its basin. Dr. W. Junk Publishers, Dordrecht.
SUNDIN L, REID SG, RANTIN FT AND MILSON WK. 2000. Branchial receptors and cardiorespiratory reflexes in a neotropical fish, the tambaqui (Colossoma macropomum). J Exp Biol 203: 1225-1239.

VAL AL. 1995. Oxygen transfer in fish: morphological and molecular adjustments. Braz J Med Biol Res 28: 11191127.

VAL AL. 2000. Organic phosphates in the red blood cells of fish. Comp Biochem Physiol 125A: 417-435

VAL AL, AFFONSO EG, SOUZA RHS, ALMEIDA-VAL VMF AND MOURA MAF. 1992. Inositol pentaphosphate in erythrocytes of an Amazonian fish, the pirarucu (Arapaima gigas). Can J Zool 70: 852-855.

VAL AL AND ALMEIDA-VAL VMF. 1995. Fishes of the Amazon and their environments. Physiological and biochemical features. Springer Verlag, Heidelberg

VAL AL, ALMEIDA-VAL VMF AND MONTEIRO PJC. 1986a. Aspectos biológicos de peixes amazônicos. IV. Padrões eletroforéticos de hemoglobinas de 22 espécies coletadas na Ilha da Marchantaria (Manaus-AM). Acta Amazonica 16/17: 125-134.

VAL AL, GOMES KRM AND ALMEIDA-VAL VMF. 2015. Rapid regulation of blood parameters under acute hypoxia in the Amazonian fish Prochilodus nigricans. Comp Biochem Physiol 184A: 125-131.

VAL AL, SCHWANTES AR AND ALMEIDA-VAL VMF. 1986b. Biological aspects of Amazonian fishes. VI. Hemoglobins and whole blood properties of Semaprochilodus species (Prochilodontidae) at two phases of migration. Comp Biochem Physiol 83B: 659-667.

VAL AL, SILVA MNP AND ALMEIDA-VAL VMF. 1998. Hypoxia adaptation in fish of the Amazon: a never-ending task. S Afr J Zool 33: 107-114.

WEBER R, FAGO A, VALAL, BANG A, VAN HAUWAEERT ML, DE WILDE S, ZAL F AND MOENS L. 2000. Isohemoglobin differentiation in the biomodal-breathing Amazon catfish Hoplosternum littorale. J Biol Chem 275: 17297-17305.

WOOD CM, IFTIKAR F, SCOTT GR, DE BOECK G, SLOMAN K, MATEY V, VALDEZ DOMINGOS FX, DUARTE RM, ALMEIDA-VAL VMF AND VAL AL. 2009. Regulation of gill transcellular permeability and renal function during acute hypoxia in the Amazonian oscar (Astronotus ocellatus): new angles to the osmorespiratory compromise. J Exp Biol 212: 1949-1964.

WOOD CM, WILSON RW, GONZALEZ RJ, PATRICK ML, BERGMAN HL, NARAHARA A AND VAL AL. 1998. Responses of an Amazonian teleost, the tambaqui (Colossoma macropomum) to low $\mathrm{pH}$ in extremely soft water. Physiol Zool 71: 658-670. 